\title{
底魚資源量の音響推定における海底基準と海底オフセットの決定
}

\author{
黄斗溱, 飯田浩二, 向井徹
}

(1994 年 7 月 7 日受付)

\begin{abstract}
Stable Bottom Detection and Optimum Bottom Offset for Echo Integration of Demersal Fish DooJin Hwang,* Kohji Iida,* and Tohru Mukai*
\end{abstract}

\begin{abstract}
This paper discusses methods for the stable bottom detection and the optimum bottom offset which enable to separate the fish echoes from the bottom echoes with echo integration of demersal fish.

In preprocessing of the echo signal, the bottom detection has to be done stably against the fluctuation of echo level and the bottom offset has to be set to a minimum height such that near bottom fish echoes are included.

Two methods of bottom detection, namely echo level threshold method and maximum echo slope method were compared and analyzed. The echo level method works well if the ideal threshold level was given but it sometimes misses the bottom because of the fluctuation of the echo. Another method to detect the bottom which uses maximum echo slope indicates the simple and stable bottom detection.

In addition, the bottom offset has to be set near to the bottom but not to include the bottom echo. Optimum bottom offset should be set a few samples before the detected bottom echo which relates the beginning of pulse shape and acoustic beam pattern to the bottom feature.
\end{abstract}

キーワード：計量魚群探知機, 底魚, 海底拾出, 海底オフセット

近年の計量魚探技術の発展は目ざましく，従来，困難 とされてきた底魚資源の調查にす利用されるようになっ た。 ${ }^{1-3)}$ 底魚には夕イ，タラ，アンコウなどの高級魚が含 まれることから，その資源量や生態を把挃するために， 今後ますます音響資愿調查が重要視されるであろう。

エコー積分法を用いて底魚の資源現存量を測定する場 合、海底の取り扱いには多くの問題点が残されている。 すなわち，送信パルスの物理的長さで決まる距離分解能 や，海底付近の魚群のエコーが音響ビーム内の海底エ コーにマスクされるといった方位分解能の制約から生ず る Dead Zone ${ }^{3-6}$ の存在, さらに海底判別のアルゴリズ ムや海底上のエコー積分の下限を決める海底オフセッ ド)の決定が適切でないために生ずる誤差などが挙げら れる。この海底オフせットは十分大きくとれ侮底エ コーを䛊って積分することはなくなるが，海底付近の魚 群エコーを積分対象から取り除いてしまう危除がある。

本論文はエコー積分法による底魚資源量評価のための 海底判別のアルゴリズムの改良と最適な海底オフセット の決定法について検討したあのである。
方法

1993 年 11 月に北海道噴火湾において，北海道大学水 産学部研究調查船うしお丸（128トン）を用い，噴火湾に 来遊するスケトゥダラ群の音響資源調查を実施した。用 いた計量魚群探知機は KFC-200型（カイジョー）で，周 波数は $25 \mathrm{kHz}$ と $100 \mathrm{kHz}$ の 2 周波で，船底装備のトラ ンスデューサを用い,パルス幅 $1 \mathrm{~ms}$ ，パルス絽返し周期 $0.35 \mathrm{~s}$, 測定レンジ $100 \mathrm{~m}$ で使用した。トランスデューサ の両周波数におけるビーム幅は $25 \mathrm{kHz} て 26.4$ 度, 100 $\mathrm{kHz}$ で 13 度であった。エコーインテグレータの皘分

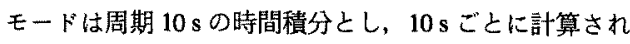

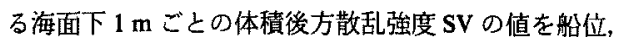
潮流, 水温などのデータとともに GPIBインターフェイ スを経由してパソコンのフロッピーディスクに記録する 之同時に，魚探信号を磁気テーフに収録した。そして後 日，現場で得た魚探信号を Fig. 1 のようにデシタタルオー ディオプロセッサを通して再生し，エコー解析装置 （DR-90，カイショー）のカラーモニタで表示すると共

* 北海道大学水産学部 (Faculty of Fisheries, Hokkaido University, Hakodate, Hokkaido 041, Japan). 
に, 両周波数の TVG 処理後の信号を分解能 12 bit の A $\mathrm{D}$ 変換器を用いてパソコンに入力し，XY プロッタで1 ピングごとの波形を描いた。次に多数の魚群が出現して いるところを選び出し, カラーモニタ上のエコーグラム とパソコンで再現したエコー波形を比較し，さまざまな

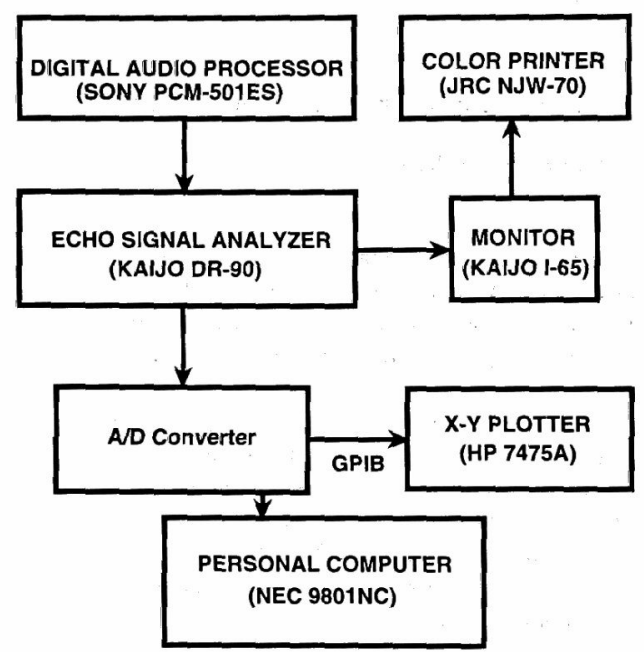

Fig. 1. Block diagram of data processing system.

\section{$25 \mathrm{kHz}$}

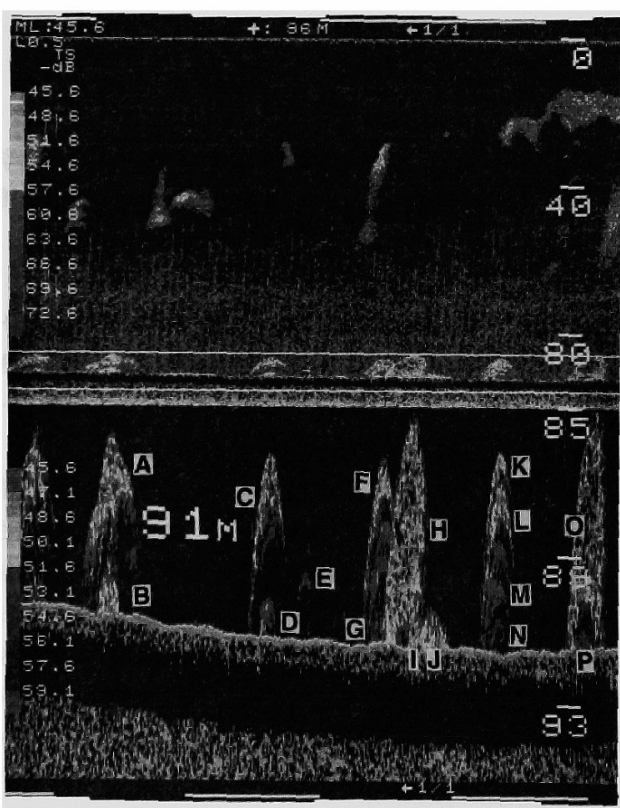

a
パターンの魚群について分析した。

結果

調查で得られたエコーグラムを Fig. 2a, b に示す。両 図上屯海底拡大表示を併記してあり，Fig. $2 a$ は $25 \mathrm{kHz}$, Fig. $2 \mathrm{~b}$ は $100 \mathrm{kHz}$ で, 上半分が海面から海底までの全体 像を, 下半分は海底上 $10 \mathrm{~m}$ 層（85 95 m) の拡大であ る。レベルスケールは上半分は $3 \mathrm{~dB}$ ステップ，下半分は $1.5 \mathrm{~dB}$ ステップである。画面に表示されている水深 (91 m) は船底加らの深さを表し, 実際の水樑は船舶の吃水 $3 \mathrm{~m}$ を加算すると $94 \mathrm{~m}$ となる。両周波数とも海底拡大 表示においてスケトウダラの産卵回遊群と見られる 16 個の魚群 $(\mathrm{A} \sim \mathrm{P})$ が確認された。

Fig. $2 a, b$ と同時刻におけるエコー波形を描いたのが Fig. 3a, b である。上半分は $25 \mathrm{kHz}$, 下半分は $100 \mathrm{kHz}$ の 波形を表し，横軸はエコーレベル (V), 縦軸は深度 (m) として表したものを時間の経過とともに左側から右側へ 連続表示したものである。また海面から深度 $85 \mathrm{~m}$ に寒

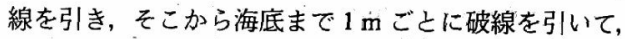
魚群が分布している深度が分かるようにした。両周波数 とも，各図の下端に出ているエコーレベルが飽和に達し ている部分が海底である。そして各々の魚群に対し Fig.

\section{$100 \mathrm{kHz}$}

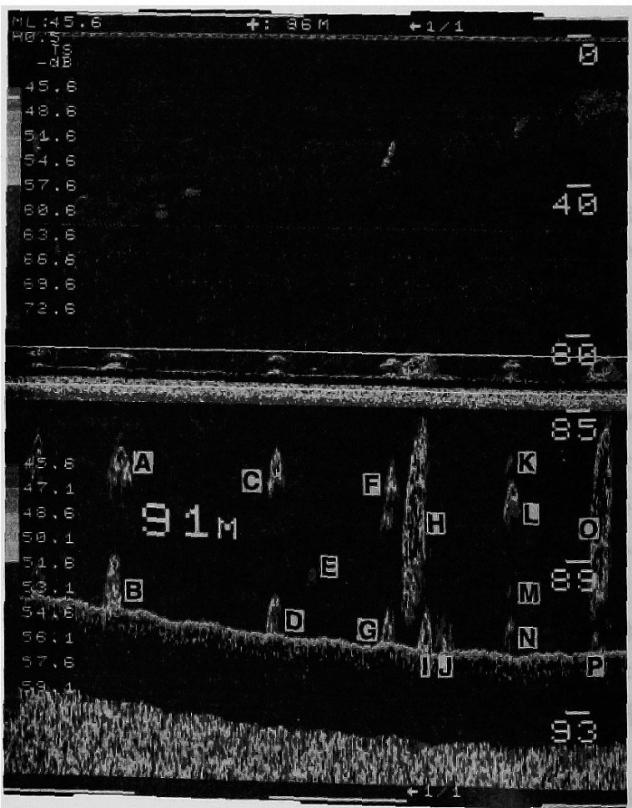

b

Fig. 2. Echograms of demersal fish school obtained by $25 \mathrm{kHz}$ (a) and $100 \mathrm{kHz}$ (b) in Funka Bay. Depth ranges are 0-95 $\mathrm{m}$ (upper) and 85-95 m (lower). 

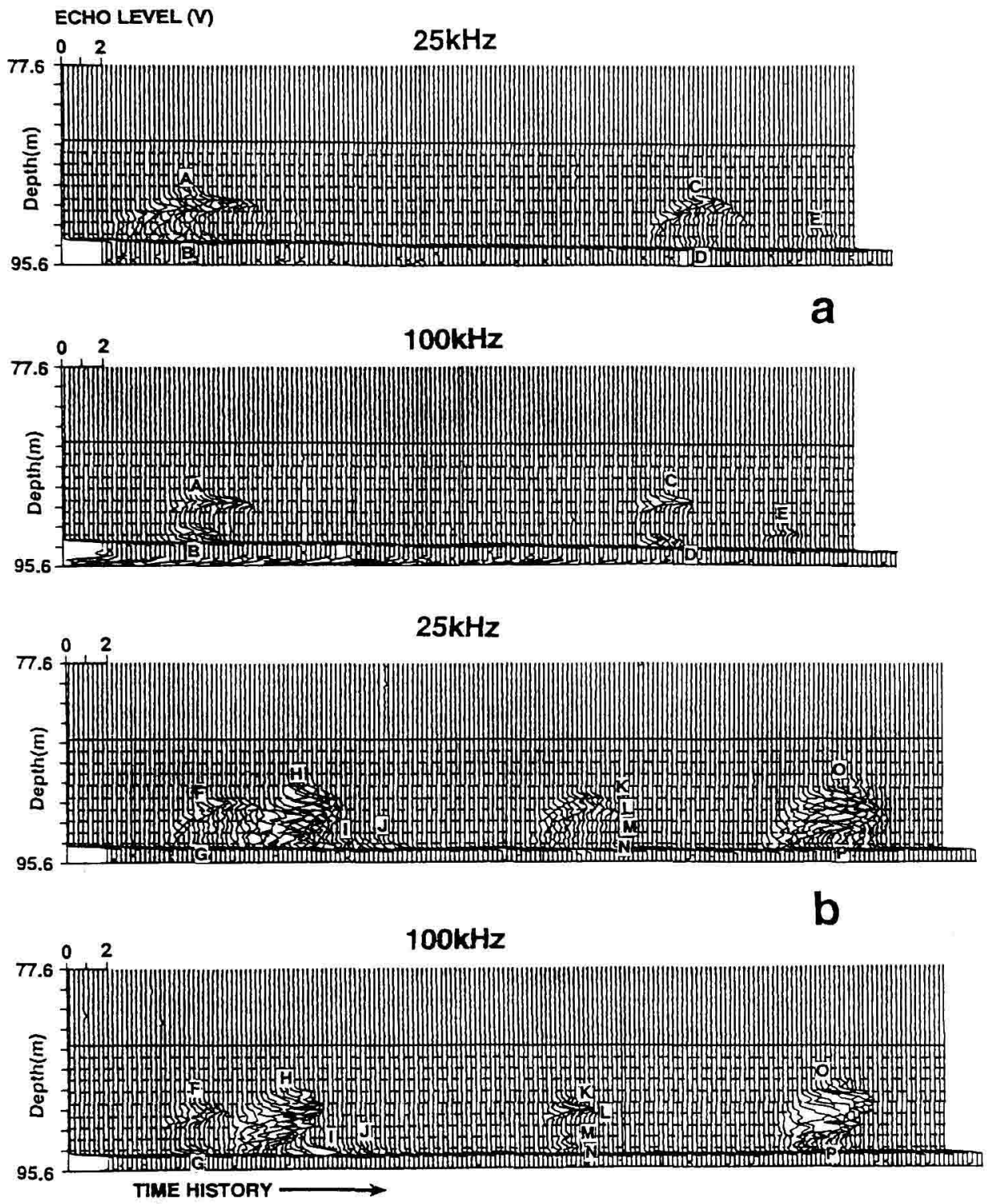

Fig. 3. Three dimensional plots of echo-envelopes from fish schools near the bottom.

2 のエコーグラムに対応する魚群 $\mathrm{A}$ から $\mathrm{P}$ までのエ コー波形を選びだした。

これらの魚群はエコーグラム上において海底から 2〜 $3 \mathrm{~m}$ 離れて分布しているように見える A, C, E, F, H, K, $\mathbf{L}, \mathbf{M}, \mathbf{O}$ と海底に付着しているように見える $\mathbf{B}, \mathbf{D}, \mathbf{G}, \mathbf{I}$, $\mathbf{J}, \mathbf{N}, \mathbf{P}$ の二つに分けられる。このような分布をする魚群 に対してェコー積分を行う場合, 海底と明確に分離して いる魚群エコーの抽出や積分は容易であるが, 海底に付
着しているように見える魚群の場合は海底と魚群とを識 別するための海底判別の精度が問題になり，この方法し だいで推定資源量に大きな䛊差を含む可能性がある。

そこで海底のエコーが海底付近の魚群エコーによ゙のよ うに影響してくるかを見るために Fig. 3 の各エコー波形 を数值化したデータ（サンプリング間隔は $15 \mathrm{~cm}$ ）を用 いて，海底付近で積分層の幅を $5 \mathrm{~m}$ に固定したときの面 積後方散乱係数 $S a_{5 m}$ を計算した。今, トランスデューサ 
から距離 $r$ に, 密度 $n$, 後方散乱断面績 $\sigma_{b s}$ の魚群が存在 した場合，それから得られるエコー電圧は次式で与えら れる。

$$
E=P \cdot M \cdot G \sqrt{\frac{c \cdot \tau}{2} \Omega} \frac{10^{-0.1 a r}}{r} \sqrt{n \cdot \sigma_{\mathrm{bs}}}
$$

ただし。
$\alpha$ : 吸収娍衰係数
$P$ : 送波音圧レベル
$M:$ 受波感度
$G$ : 受信部の利得
c: 水中音速
て: 等価パルス幅
$\Omega$ : 送受波器の等偭指向角

(1) 式において $n \cdot \sigma_{b s}$ は単位体積当たりの後方散乱断 面積を表し，これはまた体積後方散乱係数 $S v$ に等しい。 すなわち

$$
S v=\left(\frac{E}{P \cdot M \cdot G}\right)^{2} \cdot r^{2} \cdot 10^{0.2 a r} \cdot \frac{2}{c \cdot \tau \cdot \Omega}
$$

よなる。

$S a$ は $S v$ を深度 $z$ で積分したものよして定義され、

$$
S a=\int_{z_{1}}^{z_{2}} S v(z) d z
$$

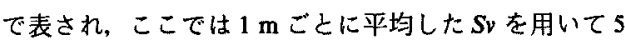
$\mathrm{m}$ 幅の $S a$ を求めるので任意の樑度から 5 個の $S v$ に関 しての積分であり

$$
S a_{5 m}=\sum_{i=1}^{5} S v_{i}
$$

とした。

そして，積分層の開始深度を $83.05 \mathrm{~m}$ から1サンプリ ング単位ずっ海底方向にシフトしながら，各水深による $S a_{s_{m}}$ の変化について検討した。もし，5m幅の積分層に 海底の一部が含まれると, $S a_{s m}$ は大きく変化する。海底 上の魚群分布形態を簡単な五つのパターンに分類して, これに対応するるSa $a_{5 m}$ の変化を模式化したのが Fig. 4 である。a図(1)のように魚群が全くない場合はb図 (1)のように海底までのSa が最低で, 海底エコーの成分 が含まれるところで急に大きくなる。また $\mathbf{a}$ 図 (2) のよ うに海底付近に魚群が集中する場合は，b図 (2)のよう に海底の近くでいったん $S a_{5_{m}}$ が高くなりその後海底エ コーの成分が增大する。

また $\mathrm{a}$ 図 (3)のように均一な魚群上海底上に集中する 魚群が湿在する場合は，b図(3)のように(2)に一定の バイアスを与えた形になる。また $\mathrm{a}$ 図 (4)のように均一 分布の場合は b 図(4)のように高い $S a_{5 m}$ に続き，海底 エコーの成分が現れる。最後に $\mathrm{a}$ 図 (5) の上うに海底に 近づく程魚群が減少する場合は, b図 (5)のように深度 ととあに $S a_{5 m}$ あ減少すると考えら机る。

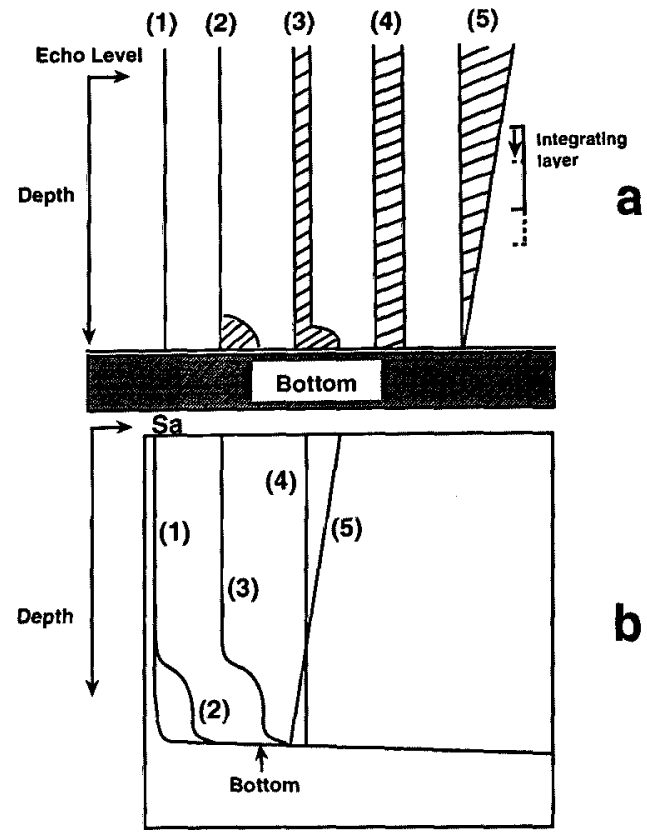

Fig. 4. Five models of fish vertical distribution and area backscattering coefficient $S a$ variation above the bottom.

Fig. 5 は観測されたいくつかの魚群について積分範聿 をシフトした時の海底上の $S a_{5 m}$ の変化をプロットした あのである。図の左側は $25 \mathrm{kHz}$, 右側は $100 \mathrm{kHz}$ のあ

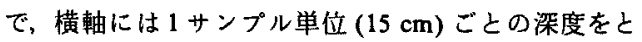
り, 縦軸にはその時の $S a_{5 m}$ を対数表示した。各図とも連 続する 6 ピング分の $S a_{5 m}$ 曲線を重ね描きした。図中の 番号は Fig. 4 で考えた五つの魚群分布パターンに対応す る。いずれの図でも海底エコー成分が現れるところ（破 線) で $S a_{5 m}$ が急に大きくなるが，特に (2) 型，(3) 型魚 群の場合は，海底エコーの直前に海底に付着した魚群の 成分が現れるという特徴的な変化を示した。したがって このような分布様式の魚群の場合は海底基準をどこにと るかによって推定誤差を生ずることは明らかである。例 えば Fig. 5 の（2）において，海底基準を破線から離れた $84.65 \mathrm{~m}$ 付近に没定した場合, それ以深の $87.05 \mathrm{~m}$ 付近 にある魚群の成分は $S a_{5 m}$ に含まれないし，逆に海底基 準を $87.65 \mathrm{~m}$ に設定すれば海底エコーの成分が積分され るといったように，海底基準をどこにとるかによって底 魚資源量の過小または過大評価を生むことになる。

\section{考察}

底魚のエコー積分において積分範囲の下限となる海底 基準の決定は魚群が海底に近い程重要になってくる。海 


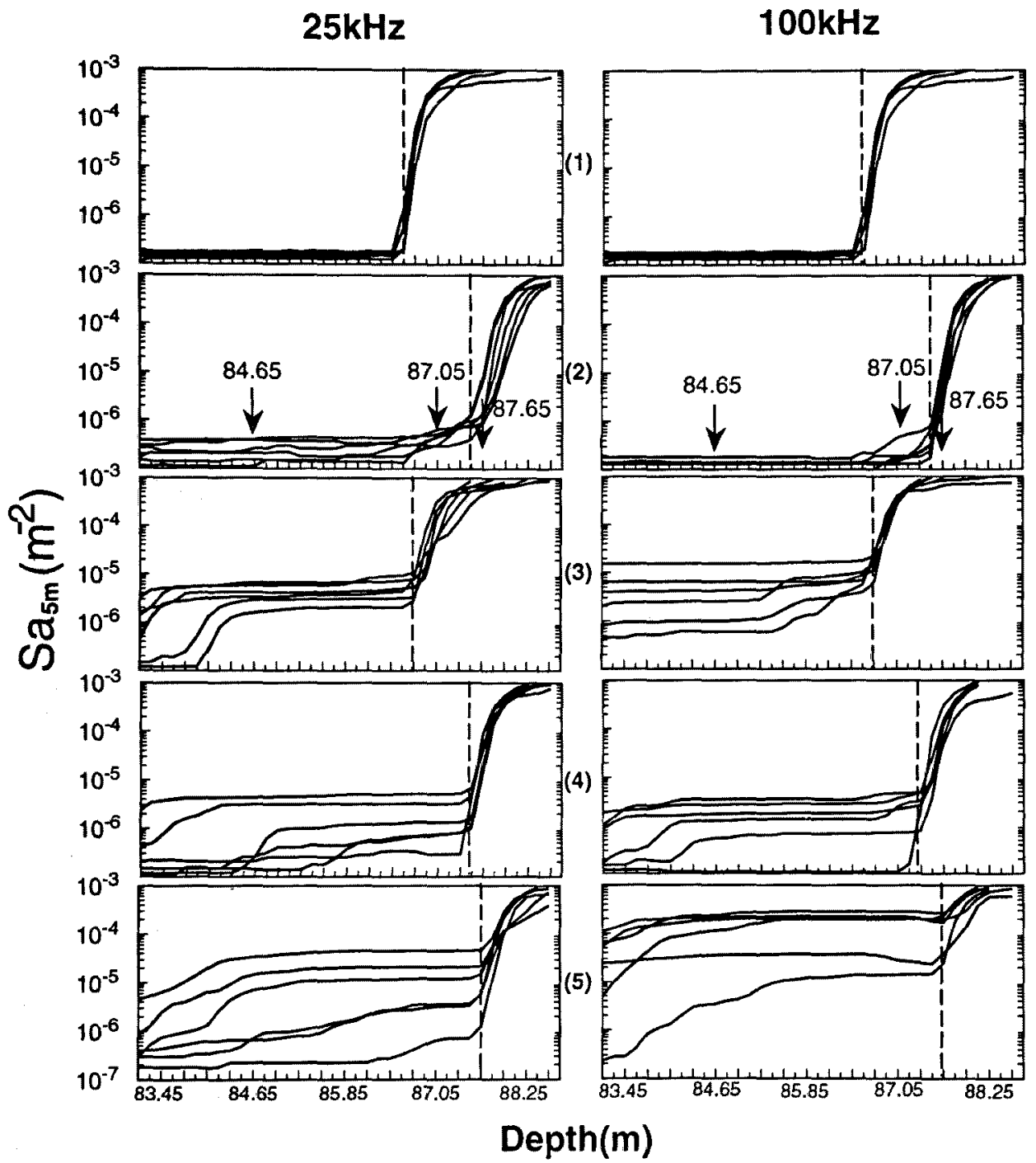

Fig. 5. Area backscattering coefficient $S a$ variation near the sea bottom. The thickness of integration layer is fixed to $5 \mathrm{~m}$.

底判別を行う一般的な万法は，海底のエコーレベルが焦 群のエコーレベルより大きい事を利用して，適当な閏値 を設定しこれを超えた瞬間を海底とするすのである。 しかしながらこの方法は閔値の設定しだいで海底エコー の誤検出につながる. Fig. 6 は闇值を変化させた時にサ ンプリングされる海底付近のエコー波形を示したもので ある。

図の左半分は $25 \mathrm{kHz}$ を, 右半分は $100 \mathrm{kHz}$ を表し, 横軸は設定した閾値を超過する瞬間を海底基準 B とし て, それ以浅の 15 サンプル点と以深の 5 サンブル点を
表し, 縦軸はエコーレベル (V)である。上から順に設定

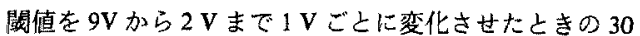
パルス分のエコー波形を重好描きしたすのである。解析 したエコー波形は海底付近に魚群が集中する Fig. 4 の (3) 型魚群である。

図をみると海底検出闌値が 5 6Vの時は海底と魚群 が忠実に表現できるが、閵値を大きく(7〜9V) すると 海底エコーレベルが低い時に，海底を検出できない機会 が增え (Fig. 6 中の Bottom detect failure)，逆に閾值を小 さく $(2 \sim 4 \mathrm{~V})$ しすぎる, 魚群エコーを海底エコーと 
$25 \mathrm{kHz}$
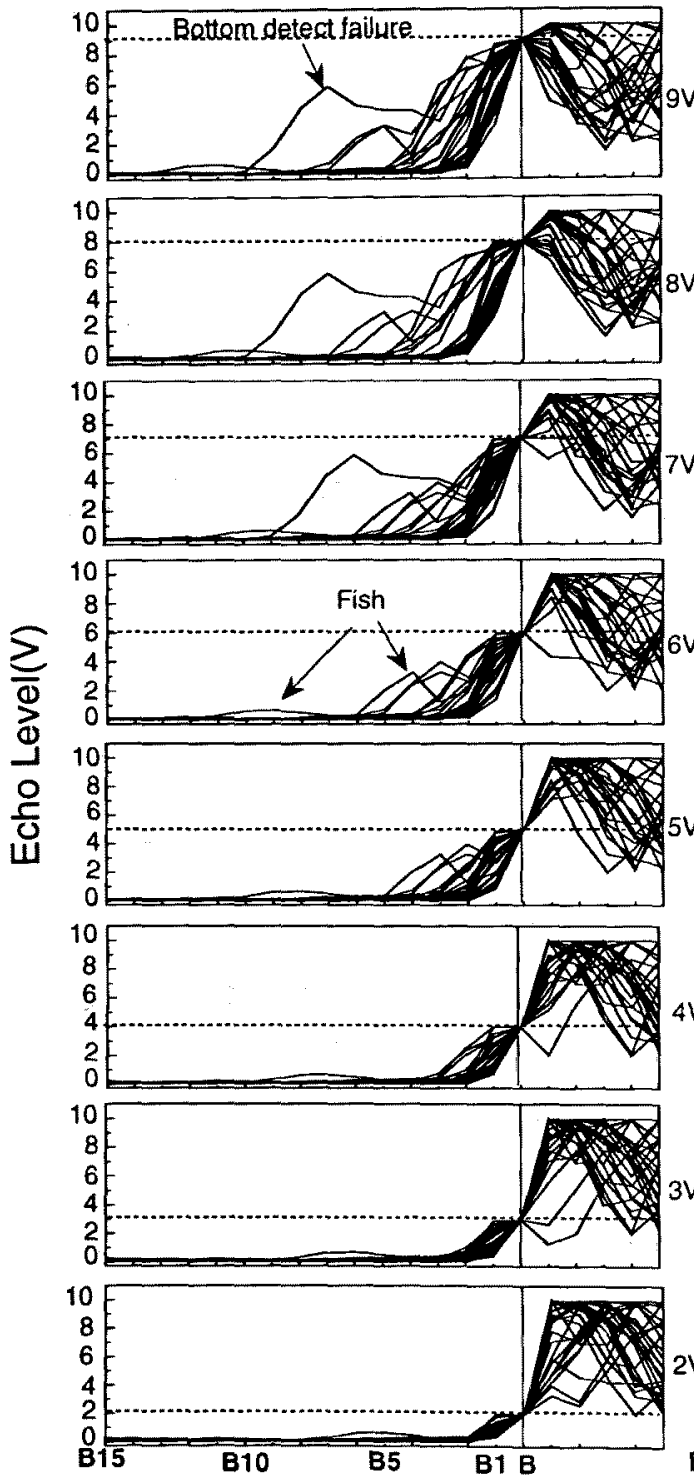

Depth(Layer)
$100 \mathrm{kHz}$
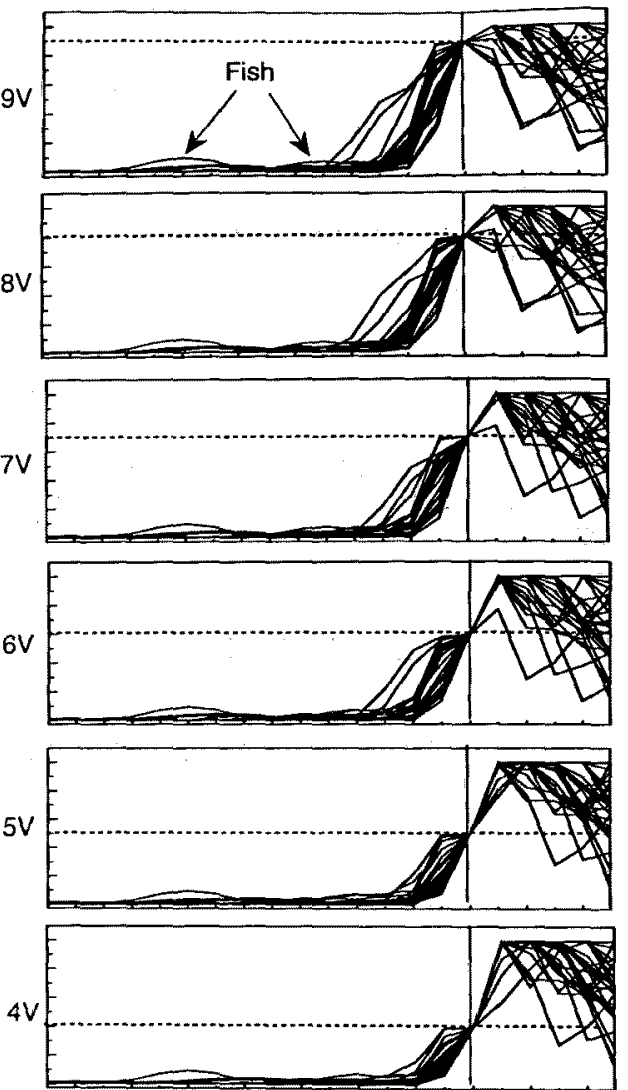

$3 \mathrm{~V}$
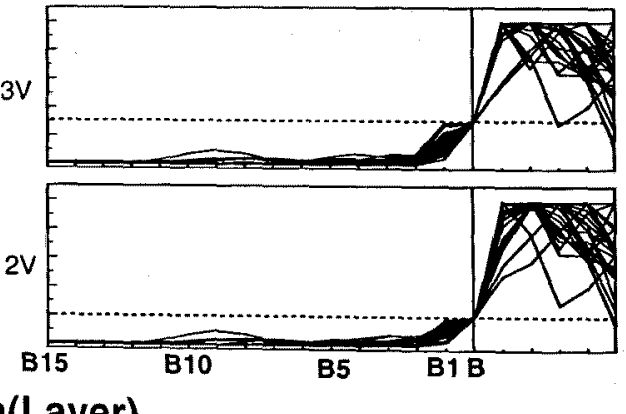

Fig. 6. Echo signal waveforms from the bottom synchronized with the threshold point. Threshold levels are changed from 20 to $90(\%)$ of the saturation level.

間違える割合が增えることがわかる。

そこで, 次に海底エコーレベルの変化率に着目し, 海 底判別への適用について検討した。すなわち，海底エ コーの形成は音袙ビームの指向特性や海低の反射特性あ るいは音響バルス波形などの時間的相互作用によって決
まるため，一般に海底エコ一波形の立ち上がりは䜌やか でその後急峻となりやがて極大を示す。その变化を次式 のようなサンプリング電生の差分として表した。

$$
\Delta V=V(t+1)-V(t)
$$

(5) 式で計算した差分電圧の変化の例を Fig. 7 に示 


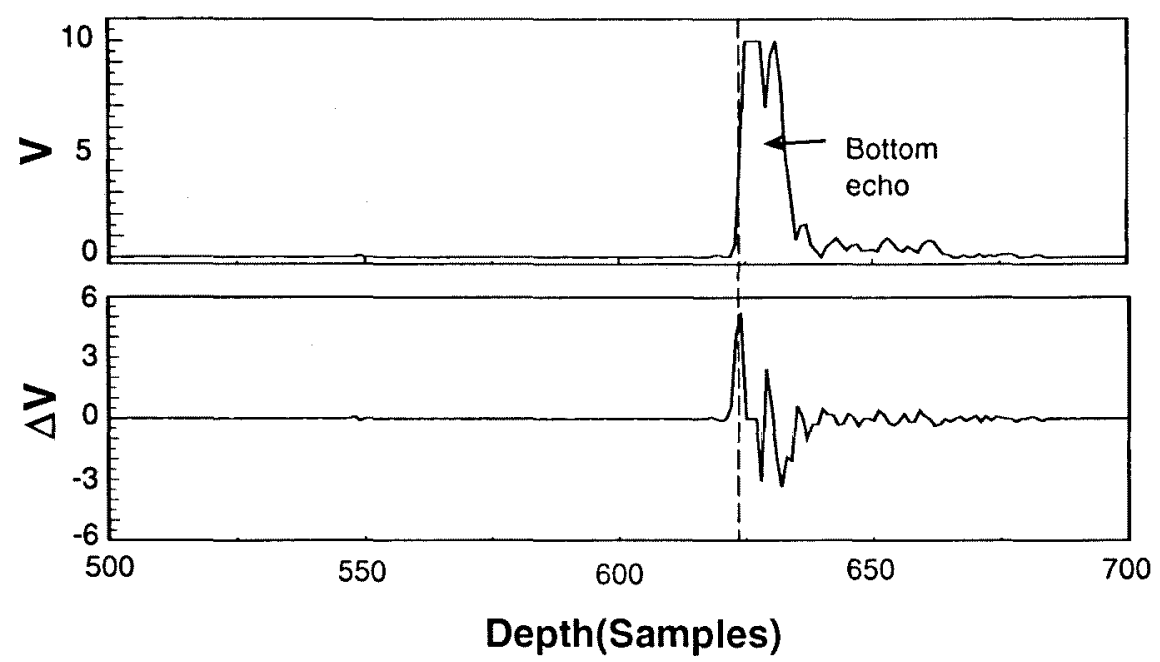

Fig. 7. Relationship between echo signal waveform and its differential waveform from the sea bottom.

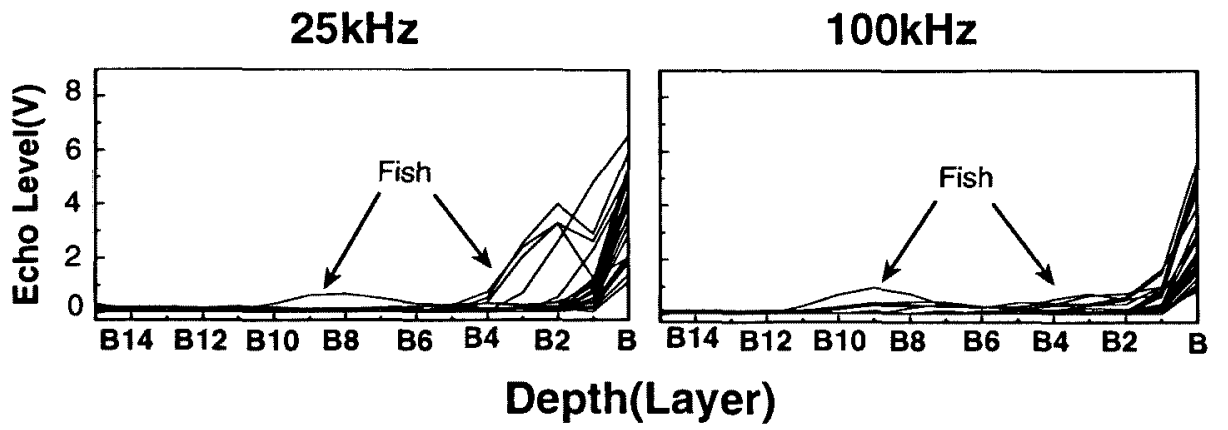

Fig. 8. Echo signal waveforms synchronized with the maximum differential of echo level.

す。上図がエコー電压波形で下図が差分電压波形であ る。横軸はサンプリング単位, 縦軸は電圧 (V) を表す。 図から電生変化量が最大になる点は唯一明確であること がわかる。そこでこれを新たな海底基準として Fig. 6 と 同様に 30 パルス分のエコー波形を表したのが Fig. 8 で ある.

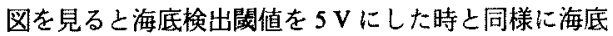
付近の魚群が忠実に表現された。またこの時の積分下限 は, 海底エコ一の立ち上がりが揃っており，かつ安定し ているので，海底基準 $\mathrm{B}$ からわずか $1 \sim 2$ サンプル単位 (0.2〜0.4 ms) で十分であり，海底オフセットを最小にす ることができると考えられた。海底エコーの立ち上がり を見ると $25 \mathrm{kHz}$ の方が $100 \mathrm{kHz}$ に比へて楥やかである が，これに対しては二つの理由が考えられる。一つパ ルス波形の立ち上がりと関係し，100 kHzの方が $25 \mathrm{kHz}$ よりパルス波形が矩形波に近い加らと考えられる。す 一つは音響ビームに関係がありビーム幅が広い 25
$\mathrm{kHz}$ の力が音響パルスが海底中央に最初に到達してか らビーム周辺のエコーが帰ってくるまでの時間が長いた めと考えられる。これに関しては今後さらに理諭的検討 が必要であろう。

$$
\text { 要 約 }
$$

計量魚群探知機を用いて底魚を対缘としたエコー積分 を行う場合，積分範囲の下限を决めるための海底基準や オフセットの瞹味さは，底魚資源量推定の愦差要因の一 つになっている。海底付近の魚群エコ一の解析から海底 基準の決定方法と最適なオフセットに関して考察した結 果，次の知見を得た。

1) 積分層の幅を $5 \mathrm{~m}$ にとり，積分範讲を 1 サンプル 単位ごとに海底方向にシフトしながら，海底付近の $S a_{5 m}$ の変化を見たところ，海底付近の魚群エコーを積分する ためには，積分範讲の下限を可能な限り海底まで近づけ なければならない。 
2) エコーレベルの闌値で海底検出を行う場合，關檤 が大き渦ざる上海底检出不能回数が增え，小さ過ぎると 海底馀出回数が增える。

3)エコーレベルの最大変化点を海定基準ししたとこ ろ, 高精度で, かつレベル変動に対し安定な海底基集と なる。

4)この方法によると最適な海底オフセットは海底基 準加ら $0.4 \mathrm{~ms}$ 以内でよく、これはバルス波形々海底地形 に対する音饙ビームに依存する。

$$
\text { 文献 }
$$

1) 朱 德山. S.A. Iverson: 黄海・菓海のカタクチイワシお 上びその他重要魚類資源の音響学的評洒研究 (大滰英 夫)，資料 No.32，海洋水産資源開発センター，東京，1991， pp. 56-57.

2）黄 斗溙，佐野典達，飯田浩二，问井 徹，增田紀義， 佐々木成二: エコー積分とトロールデータから算出した 東シナ海における底楼魚嗾の夕ーダットストレングスに ついて. 北大水应策報, 44, 197-208 (1993).

3) Egil ONA: Hydroacoustic method for estimation of demersal fish resources, in "Proceedings of International Symposium on the Investigation of Demersal Fish Resources", Hokkaido University, Hakodate, 1993, pp. 22-34.

4) R. B. Mitson: Acoustic detection and estimation of fish near the sea bed and surface. FAO Fish. Rep., 300, 27-34 (1983).

5) R. B. Mitson: FISHERIES SONAR (incorporating Underwater Observation using Sonar by D. G. Tucker), Fishing News Books, Ltd., England, 1983, pp. 156-169.

6) K. A. Johannesson and R. B. Mitson: Fisheries acoustics; A practical manual for aquatic biomass estimation, FAO Fisheries Technical Paper, 240, FAO, Rome, 1983, pp. 155-180. 